\title{
Důchodový systém: klíčový piliŕr sociální politiky státu
}

\author{
Michal VANĚK, Jana MAGNUSKOVÁ, Simona MATUŠKOVÁ, VŠB-TU Ostravai
}

\begin{abstract}
Retirement income policies belong to fundamentals of any welfare state. The current demographic development in the Czech Republic reflects badly on its retirement income strategies. This fact should attract our constant attention. There is no doubt that a pension scheme reform is a top priority. This paper focuses not only on the domestic retirement income planning and suggested change but also provides for the brief on approaches to retirement income planning in the neighbouring countries of Slovakia, Austria, Germany, and Poland. The paper also gives and discusses results of sociological investigation concerning retirement income strategies.
\end{abstract}

\section{Keywords}

Family savings, pension system, risk, sociological research.

JEL Classification: C12, D14, G23

\footnotetext{
${ }^{i}$ Institute of Economics and Control Systems, Faculty of Mining and Geology, Technical University of Ostrava, 17. listopadu 15, 70833 Ostrava - Poruba, Czech Republic.

michal.vanek@vsb.cz (corresponding author)
}

\section{1. Úvod}

Moderní stát 21. století se neobejde bez efektivní sociální politiky, která stojí na principu solidarity (např. mezigenerační solidarity, solidarity zdravých a nemocných). Nelze předpokládat, že budeme vždy solventní, zaměstnaní, zdraví. Proto způsob, jakým stát, potažmo nadnárodní společenství (např. EU), řeší sociální problematiku, by neměl stát na pokraji našich zájmů. Lze dokonce říci, že společnost je tak silná, jak se dokáže postarat o sociálně potřebné občany.

Sociální politika je široké téma, a proto se jí v našem článku nebudeme věnovat $\mathrm{v}$ plné širri. Zaměrríme se pouze na oblast mezigenerační solidarity, která je reprezentována důchodovou politikou. Vedoucí představitelé EU se shodli na tom, že důchodové a zdravotní pojištění jsou základními právy zaměstnanců, avšak náklady na ně musí být udržitelné (Činnosti Evropské unie - Zaměstnanost a sociální věci, 2009.).

Členství ČR v EU nemá žádný vliv na výši důchodů. Předpisy, kterými se bude důchodové zabezpečení řídit, zůstávají nadále $\mathrm{v}$ kompetenci členských států (Sociální zabezpečení-občan, 2009).

Důchodová politika a problematika týkající se života seniorů je ve stárnoucí Evropě jednou z významných oblastí, která nemůže být opomíjena. Závažnost důchodové problematiky je umocněna dlouhodobě nepř́iznivým demografickým vývojem a s ním spojenou otázkou financování důchodového systému.

Hrozba nestability důchodového systému je aktuální ${ }^{1}$ i pro Českou republiku. Reforma v této oblasti je proto nutná a naléhavá. Některé reformní kroky již byly implementovány (zvýšení hranice odchodu do důchodu na 65 let věku), jiné kroky jsou připraveny v podobě návrhů (např. opt-out). Domníváme se, že může být zajímavé i př́nosné znát názory občanů -

\footnotetext{
1 Schodek na účtu, ze kterého se vyplácejí důchody a nemocenské, narůstá. Po prvním čtvrtletí na něm chybí 10,4 miliardy korun, 2010.
} 
potencionálních uživatelů důchodového systému - na problematiku starobních důchodů a změny, které se v důchodovém systému připravují. Rovněž může být zajímavá informace o tom, jaké další investiční př́ležitosti občané ve spoření na důchod $\mathrm{v}$ současnosti využívají. Proto jsme se rozhodli provést sociologický výzkum, jehož výsledky náš článek prezentuje.

\section{Důchodový systém v ČR a ve vybraných okol- ních státech}

V České republice je důchodové pojištění a související problematika $\mathrm{v}$ gesci Ministerstva práce a sociálních věcí. Základní důchodové pojištění a zvýšení důchodu pro bezmocnost tvoří spolu s nemocenským pojištěním součást sociálního zabezpečení ve smyslu zákona č. 582/1991 Sb., o organizaci a provádění sociálního zabezpečení, ve znění pozdějších předpisů (Ministerstvo práce a sociálních věcí, 2009a).

Důchodový systém ČR je tvořen dvěma piliŕri:

- piliŕr - povinné základní důchodové pojištění průběžně financované ${ }^{2}$;

- piliřr - dobrovolné doplňkové penzijní připojištění financované kapitálově, prričemž účastníkům náleží státní prríspěvek.

První pilír je univerzální a zabezpečuje všechny ekonomicky aktivní osoby, právní úprava je jednotná pro všechny pojištěnce, neexistují speciální odvětvová schémata apod. Pouze $\mathrm{v}$ oblasti organizačního a administrativního zabezpečení platí určité odchylky pro tzv. silové resorty (např. vojáci, policisté, celníci, hasiči). Důchod ze základního důchodového pojištění pobírá více než $99 \%$ obyvatel ve věku vyšším, než je věková hranice pro nárok na starobní důchod (Ministerstvo práce a sociálních věcí, 2009a).

Penzijní připojištění se státním příspěvkem je možno podle terminologie EU považovat za třetí pilíř důchodového systému. Součástí třetího pilíře jsou

\footnotetext{
2 Jedná se o tzv. PAYG systém. Kromě něj se lze setkat $\mathrm{s}$ fondovým financováním důchodového systému (FF).
}

i produkty komerčních pojišt'oven - zejména životní pojištění. Důchody přiznávané ze třetího piliřre se zatím podílejí na př́jmech důchodců zanedbatelnou měrou. ${ }^{3}$ (Ministerstvo práce a sociálních věcí, 2009a).

Základním hmotně právním předpisem, který upravuje nároky na důchody ze základního důchodového pojištění, způsob stanovení výše důchodů a podmínky pro jejich výplatu, je zákon č. 155/1995 Sb., o důchodovém pojištění, ve znění pozdějších předpisů, který nabyl účinnosti dnem 1. ledna 1996 (Ministerstvo práce a sociálních věcí, 2009a).

Společensko-ekonomické změny, které proběhly na počátku 90 . let minulého století, se odrazily mimo jiné i ve změněném životním stylu, což lze dokumentovat na následujících demografických údajích, viz tabulka 1. K zachování populace je žádoucí, aby se ukazatel pohyboval okolo hodnoty 2,1 potomků na jednu ženu. Pohledem na tabulku 1 zjistíme, že k této hodnotě jsme se u nás přiblížili pouze $\mathrm{v}$ roce 1990 . Na počátku nového tisíciletí byly již hodnoty velmi vzdálené svému optimu, nebot' propad činil 0,455 potomků na jednu ženu.

Ze statistických údajů můžeme dále vyčíst pozitivní trend v naději na dožití mužů i žen. Lze očekávat, že většina s tímto vývojem v zásadě souhlasí, zejména není-li stáŕí provázeno zdravotními či jinými problémy, které si naprostá většina mladých lidí nepřipouští.

Prodlužování průměrného věku má však také za následek, že se prodlužuje doba, po kterou občané budou pobírat starobní důchod, což společně se snižujícím se počtem narozených dětí podkopová stabilitu stávajícího důchodového systému. Proto Vláda ČR svým usnesením č. 656 ze dne 23. Června 2004 schválila zřízení funkce koordinátora pro přípravu podkladů pro rozhodnutí o důchodové reformě.

\footnotetext{
${ }^{3}$ V členských státech EU obvyklý druhý pilíř (zaměstnavatelské penzijní systémy) $\mathrm{v}$ českém důchodovém systému neexistuje.
}

Tabulka 1 Úhrnná plodnost

\begin{tabular}{|l|c|c|c|c|c|c|c|c|c|c|}
\hline Rok & $\mathbf{1 9 9 0}$ & $\mathbf{1 9 9 5}$ & $\mathbf{2 0 0 0}$ & $\mathbf{2 0 0 1}$ & $\mathbf{2 0 0 2}$ & $\mathbf{2 0 0 3}$ & $\mathbf{2 0 0 4}$ & $\mathbf{2 0 0 5}$ & $\mathbf{2 0 0 6}$ & $\mathbf{2 0 0 7}$ \\
\hline Úhrnná plodnost & 1,893 & 1,278 & 1,144 & 1,146 & 1,171 & 1,179 & 1,226 & 1,282 & 1,328 & 1,438 \\
\hline
\end{tabular}

Zdroj: ČSÚ

Tabulka 2 Naděje na dožití mužů a žen při narození

\begin{tabular}{|c|c|c|c|c|c|c|c|c|c|c|c|}
\hline Rok & 1995 & 1998 & 1999 & 2000 & 2001 & 2002 & 2003 & 2004 & 2005 & 2006 & 2007 \\
\hline $\begin{array}{l}\text { Naděje dožití mužů } \\
\text { při narození }\end{array}$ & 69,7 & 71,1 & 71,4 & 71,6 & 72,1 & 72,1 & 72,0 & 72,5 & 72,9 & 73,4 & 73,7 \\
\hline $\begin{array}{l}\text { Naděje dožití žen } \\
\text { při narození }\end{array}$ & 76,6 & 78,1 & 78,1 & 78,3 & 78,4 & 78,5 & 78,5 & 79,0 & 79,1 & 79,7 & 79,9 \\
\hline
\end{tabular}

Zdroj: ČSÚ 
Funkcí koordinátora byl pověřen Ing. Vladimír Bezděk a vznikla tak tzv. Bezděkova komise, která v roce 2005 předložila svou závěrečnou zprávu.

Komise neměla vůbec jednoduché zadání, nebot' východiskem její práce byly varianty důchodové reformy, jež pocházely z dílen politických stran, které delegovaly do komise své členy.

V závěru závěrečné práce tzv. Bezděkovy komise se lze mimo jiné dočíst: $V$ di̊chodovém systému pưsobí navzájem protichi̊dné vlivy. Výhody pro část populace lze ziskat pouze na úkor jiné části obyvatelstva. Neexistuje taková reforma, která by nikomu nezhoršila a alespoň někomu zlepšila př́jmovou perspektivu v důchodovém věku. Neexistuje ekonomicky ideální důchodová reforma nebo ideálni důchodový systém. Proto rozhodnutí o di̊chodové reformě a budouci podobè důchodového systému musí mit výhradně politický charakter. Jedině politici mají mandát učinit rozhodnutí o vzájemně protichůdných prvcích důchodového systému. Rozhodnutí o důchodové reformè je rozhodnutím o tom, co má být obětováno jeho stabilitě. Nelze mit současně vysoké dưchody, nizký důchodový věk a nizkou príspěvkovou sazbu, resp. levný důchodový systém (Ministerstvo práce a sociálních věcí, 2005).

V lednu 2010 se sešla tzv. Bezděkova komise II, složená z odborníků na důchodový systém, jejíž založení inicioval ministr financí Eduard Janota. Její činnost potrvá do konce funkčního období současné vlády. Komise chce opráśit propočty variant důchodové reformy vypracované již před pěti lety. Bude přitom vycházet hlavně $\mathrm{z}$ budoucího ekonomického a demografického vývoje $\mathrm{v}$ zemi. Tým se ale již nebude zabývat politickými variantami řešení. Vypracované scénáře by dle ministra Janoty měly sloužit zejména novému ministru financí, který povede tento úřad po letošních volbách do sněmovny (Bezděkova komise II: Změňte penze! 2010).

V programovém prohlášení Vlády ČR z roku 2007 byly nastíněny kroky, kterými vláda chtěla zahájit reformu důchodového systému. Zamýšlené změny v důchodovém systému byly plánovány ve třech etapách:

1. etapa - parametrické změny průběžného systému;

2. etapa - oddělení majetku akcionář a klientů u systému dobrovolného důchodového připojištění; motivace $\mathrm{k}$ vyšším příspěvkům a vyšší participaci zaměstnavatelů; vytvoření rezervního důchodového fondu a zrrízení samostatné kapitoly státního rozpočtu pro financování důchodového pojištění;
3. etapa vytvoření dalšího dobrovolného pilíre důchodového systému založeného na možnosti opt-out.

Vládě se podařilo nejen formulovat ideje důchodové reformy, ale část těchto idejí přetavit do platných legislativních norem. Novelou zákona č. 306/2008 Sb., kterou se mění zákon č. 155/1995 Sb., o důchodovém pojištění, ve znění pozdějších předpisů, zákonem č. 582/1991 Sb., o organizaci a provádění sociálního zabezpečení, ve znění pozdějších předpisů, a některými dalšími zákony došlo mimo jiné $\mathrm{k}$ posunutí hranice důchodového věku na 65 let u pojištěnců narozených po roce 1968. Pro úplnost dodejme, že u žen se hranice důchodového věku snižuje podle počtu vychovaných dětí. Pro účely financování reformy vytvořila vláda ve státním rozpočtu samostatný rezervní účet. Na nový účet se budou do roku 2010 vkládat jednak přebytky důchodového pojištění a jednak dividendy $\mathrm{z}$ Ceské přenosové soustavy a z regionálních distributorů elektřiny.

Odstupující vláda dne 5. 5. 2009 předložila Poslanecké sněmovně vládní návrh zákona o penzijním spoření (sněmovní tisk č. 825) a vládní návrh zákona, kterým se mění některé zákony v souvislosti s přijetím zákona o penzijním spoření (sněmovní tisk č. 826). Návrh zákona o penzijním spoření významným, ne-li zásadním způsobem změní stávající dobrovolný piliŕ důchodového systému. Účastník si bude moci vybrat z trojice povinných účastnických fondů (povinný konzervativní fond, povinný smíšený fond a povinný dynamický fond) a prípadně dalších fondů vytvářených penzijní společností. Novinkou bude, že fondy budou moci být i ve ztrátě, což dnes není možné.

Neočekává se, že tzv. úřednická vláda premiéra Jana Fišera rozhodne $\mathrm{v}$ oblasti penzijní reformy. Pokračování penzijní reformy tak zjevně čeká na novou vládu vzešlou z voleb do Poslanecké sněmovny konaných na konci května letošního roku. Vytvořil se tak časový prostor pro další diskuzi, která by dle našeho názoru měla proběhnout $\mathrm{v}$ duchu českého prŕísloví: Dvakrát měř, jednou řež!

Podívejme se nejprve, jaké jsou trendy v penzijních systémech a jak je důchodový systém nastaven $\mathrm{v}$ sousedních státech.

\subsection{Trendy $v$ důchodových systémech}

Ve všech vyspělých zemích se neustále prodlužuje střední délka života a porodnost naopak klesá, což má za důsledek stárnutí obyvatelstva. Již nyní je méně než každý šestý Evropan starši 65 let. Tlak na penzijní systémy se tudíž neustále zvyšuje a výplata penzí zatěžuje státní rozpočty mnoha zemí stále více. Proto se vlády snaží tento nepř́iznivý stav řešit. $V$ této snaze můžeme nalézt následující tendence: 


\section{A. Zvyšování důchodového věku}

Ve většině vyspělých zemí světa je již nyní důchodový věk 65 let pro muže i ženy. Zvyšování důchodového věku se zavádí postupně a $\mathrm{v}$ některých zemích je důchodový věk ještě vyšší:

- ve Velké Británii je důchodový věk v současnosti 65 let pro muže a 60 let pro ženy, dochází však $\mathrm{k}$ jeho postupnému zvyšování, $\mathrm{v}$ roce 2020 budou ženy odcházet do důchodu rovněž v 65 letech, v roce 2024 bude důchodový věk činit 66 let, $v$ roce 2034 bude činit 67 let a $v$ roce 2044 bude dokonce 68 let,

- v Norsku je důchodový věk 67 let pro muže i ženy,

- na Islandu je důchodový věk 67 let pro muže i ženy,

- v Dánsku je důchodový věk 65 let, postupně se však zvyšuje na 67 let od roku 2024 pro všechny,

- v USA je důchodový věk 66 let pro muže i ženy, postupně se však zvyšuje na 67 let.

\section{B. Znevýhodňování předčasného důchodu}

S prodlužováním důchodového věku se zvyšuje počet občanů využívajících možnosti odejít do předčasného důchodu. Přestože je předčasný důchod nižší než starobní, jeho obliba v Evropě stoupá, a proto dochází ve většině evropských zemí $\mathrm{k}$ jeho finančnímu znevýhodnění a zvýšení věku pro nárok na něj, např.:

- ve Francii je možné odejít do předčasného důchodu již v 55 letech, ale penze je za každý rok odchodu do důchodu dříve krácena o $7 \%$,

- ve Španělsku je možné odejít do předčasného důchodu v 61 letech, ale penze je za každý rok odchodu do penze dříve krácena o 6,8 \%,

- v Portugalsku je možné odejít do předčasného důchodu v 55 letech, ale penze je za každý rok odchodu do penze dříve krácena o 4,5 \%.

\section{Zvyšování potřebného počtu let pojištění}

$\mathrm{V}$ České republice je potřeba $\mathrm{v}$ současné době splnit podmínku 25 let pojištění, tato potřebná doba pojištění se však postupně zvyšuje a v roce 2018 musí každý český občan splnit podmínku 35 let pojištění. $\mathrm{V}$ západní Evropě je počet let pojištění ještě vyšší. Ve většině zemí musí již ted' být splněna podmínka 40 let pojištění, v Nizozemí a Belgii je to dokonce 45 let pojištění.

\section{Zvyšování úlohy dobrovolného spoření}

V současné době např. ve Velké Británii, USA, Irsku, Novém Zélandu nebo Japonsku dosahuje státní penze z průběžného systému cca $40 \%$ čistého př́ijmu dosahovaného před odchodem do důchodu u občana pobírajícího celý život průměrnou mzdu.
V těchto zemích je vlastní spoření nutností a tento trend se přesouvá i do dalších vyspělých zemí. Př́ijmy $\mathrm{z}$ dobrovolného spoření $\mathrm{v}$ různých finančních produktech jsou dokonce nejdůležitějším př́ijmem občanů v důchodu v USA, Velké Británii, Irsku, Nizozemí a Dánsku.

V Evropě si na vlastní penzi začínají nejdříve spořit Britové, a to v průměru již od 28 let. Vyspělé státy dobrovolné spoření vítají a podporují, např. státním př́spěvkem při splnění zákonných podmínek u podporovaného finančního produktu (v ČR u penzijního připojištění) nebo možností snížit si daňový základ o zaplacené částky na podporovaném produktu (v ČR u penzijního připojištění a u životního pojištění).

Jakou podobu má důchodový systém u našich sousedů, nabízí krátká exkurze, která začne u našeho východního souseda na Slovensku.

\section{Důchodový systém na Slovensku}

Důchodový systém na Slovensku podobně jako u nás prochází reformními kroky a lze konstatovat, že se od toho českého systému mírně liší. Od roku 2005 jej charakterizuje existence více důchodových pilír̆u dvou povinných, kdy se v termínu od 1. ledna 2005 do 30. června 2006 Slováci v aktivním věku mohli rozhodnout, zda svůj budoucí starobní důchod chtějí dostávat $\mathrm{z}$ jednoho nebo $\mathrm{z}$ obou zdrojů. Tyto jsou navíc doplněny o třetí, dobrovolný pilíŕ důchodového systému.

První piliřr (tzv. průběžný důchodový systém) představuje povinný systém, který reprezentuje Sociální pojišt'ovna. Uplatňuje se $\mathrm{v}$ něm princip celospolečenské solidarity v kombinaci se zásluhovostí. Do něj jsou v současnosti zapojeni všichni občané v aktivním věku a jejich zaměstnavatelé, kteří povinně odvádějí z každé mzdy zákonem stanovené pojistné ( $4 \%$ z vyměřovacího základu zaměstnanec, $14 \%$ jeho zaměstnavatel). $V$ př́padě, že je občan zapojený jen do prvního pilíře, je za něj celkově odváděno $18 \%$ z jeho vyměřovacího základu prímo do Sociální pojišstovny. Sociální pojišt'ovna tyto částky ihned použije na výplatu důchodů pro současné důchodce. Od 1. ledna 2004 je starobní důchod vypočítáván dle počtu odpracovaných let (let pojišstění) a př́ijmu občana za celý aktivní život. Kromě starobních důchodů Sociální pojišt'ovna vyplácí také pozůstalostní důchody a invalidní důchody.

Průměrný slovenský starobní důchod ke konci července 2009 dle zveřejněných údajů Sociální pojištovny činil 337,38 euro (10 164 slovenských korun). Důchody se zvyšují v závislosti na meziročním růstu spotřebních cen a meziročním růstu průměrné mzdy. Dle Ministerstva práce, sociálnych vecí a rodiny Slovenskej republiky činila statisticky zjištěná průměrná mzda za rok 2009 766,41 eur (23 089 sloven- 
ských korun). Z toho vyplývá, že současný průměrný slovenský důchod tvoří asi $44 \%$ průměrné hrubé měsíční mzdy.

Druhý pilíř (povinný dnes již pro všechny čerstvé slovenské absolventy škol poprvé zaměstnané, resp. podnikající) reprezentují soukromé důchodové správcovské společnosti (DSS). Jde o soukromý, tzv. kapitalizační pilíŕ, který na Slovensku vznikl 1. ledna 2005. Pokud se slovenští občané rozhodli zapojit i do tohoto druhého pilíře, část odvodů, které jejich zaměstnavatel dosud zaplatil do Sociální pojištovny, půjde na jejich osobní důchodový účet ve vybrané důchodové správcovské společnosti. Celková výše odvodů se tedy nemění, jen došlo $\mathrm{k}$ rozdělení peněz mezi první a druhý piliřr. $\mathrm{V}$ případě, že občan spoří současně v prvním i druhém piliři, je z jeho vyměřovacího základu odváděno pojistné ve výši $9 \%$ do Sociální pojišt'ovny a $9 \%$ do vybrané důchodové správcovské společnosti.

Peníze na osobních důchodových účtech se prostřednictvím důchodových fondů investují a zhodnocují tak, aby jejich hodnota postupně rostla a při odchodu do důchodu byla co nejvyšší. V tomto prŕpadě budou občané dostávat starobní důchod ze dvou zdrojů - první část ze Sociální pojišstovny a druhou část ze svých peněz, naspořených a zhodnocených na jejich osobním důchodovém účtu. Za období, kdy přispívali současně do prvního i druhého pilíře, bude jejich důchod $\mathrm{z}$ prvního pilíře snížen o polovinu a nahrazen právě důchodem $\mathrm{z}$ druhého pilíře. Výhodou vstupu do druhého pilíře je i to, že peníze na osobním důchodovém účtu jsou soukromým majetkem a $\mathrm{v}$ prŕpadě úmrtí jej mohou zdědit pozůstalí. Stát je navíc finálním garantem fungování druhého pilíre (dle zákona o ochraně vkladů zavedl slovenský stát pro spoření na důchod $\mathrm{v}$ tomto pilíríi prrísná pravidla, jejichž dodržování podléhá pěti stupňưm kontroly, ze kterých nejvýznamnější je dohled Národní banky Slovenska, navíc peníze na účtech jsou v průběhu celé doby spoření majetkem spořitele a jsou odděleny od majetku DSS).

Vzhledem k probíhající krizi na finančních trzích a následnému znehodnocování úspor slovenská vláda koncem roku 2008 nabídla občanům ještě jednu možnost, a sice vystoupení $\mathrm{z}$ druhého pilíře důchodového spoření do konce června 2009.

Třetí pilír (dobrovolný) reprezentují doplňkové důchodové společnosti (DDS), ve kterých je možné se na důchod zabezpečit bez ohledu na to, zda se občané rozhodnou vstoupit i do druhého pilíre, nebo budou přispívat výlučně do Sociální pojištovny. Př́íspěvky do třetího pilíŕe jsou hrazeny ze mzdy dle vlastního rozhodnutí a určitou částkou do něj obvykle prrispívá i jejich zaměstnavatel. DDS zhodnocují vklady svých klientů a zavazují se vyplácet účastníkovi doplňkový důchod po splnění podmínek určených ve smlouvě. Navíc je toto zabezpečení na důchod státem daňově zvýhodněno. Je však třeba dodat, že doplňkové důchodové spoření nekryje žádná rizika, jde jen o spoření.

Slovenský stát dal lidem možnost zvážit svůj výstup z druhého pilíre. Zároveň je však občanům nadále umožněno do druhého piliŕre vstupovat. Že se ani takto nastavený systém neobejde bez problémů, svědčí mnoho debat ve slovenských médiích či článků v tisku, kdy stát i DSS živě diskutují právě o výhodnosti či nevýhodnosti druhého pilíře. V těchto diskusích se často používají neférové praktiky, kdy se navzájem obě strany obviňují. Hlavním důvodem těchto sporů jsou přirozeně peníze $\mathrm{z}$ odvodů pojistného - ty jsou lákavé jak pro stát, který prostřednictvím Sociální pojišt'ovny může s větším rozpočtem nabízet voličsky atraktivní sociální balíčky, tak i pro jednotlivé správcovské společnosti (více spořitelů znamená vyšší zisk). Důchodová reforma na Slovensku proto zdaleka není u konce.

\section{Důchodový systém v Rakousku}

Rovněž Rakousko přistoupilo k postupnému zvyšování věku odchodu do důchodu. Dnes platí věková hranice odchodu do důchodu 65 let pro muže a 60 let pro ženy, mezi lety 2024 až 2034 má dojít k vyrovnání na 65 let pro všechny.

Za zmínku stojí, že dříve se rozlišoval pojem př́jemce starobního důchodu, který zahrnoval státní zaměstnance, a pojem príjemce renty, což byli pracující v soukromé sféře. Dnes je to již sjednoceno, všichni jsou př́ijemci starobních důchodů, za príijemce renty jsou $\mathrm{v}$ současné době označováni př́jemci důchodů invalidních.

V Rakousku je povinný základní průběžně financovaný penzijní systém. Pokrývá téměř $100 \%$ ekonomicky aktivní populace. Je zajištován samostatnými pojišt'ovacími subjekty sdruženými $\mathrm{v}$ Hlavním svazu rakouských nositelů sociálního pojištění. Do státního penzijního systému povinně přispívají za-

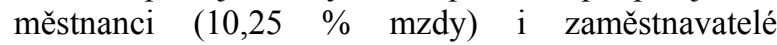
$(12,55 \%)$. Systém je značně členitý podle profesí (samostatné pojišt'ovací systémy pro horníky, železničáře, státní zaměstnance...).

Rakousko se snaží podporovat také vlastní penzijní spoření, které má rostoucí tendenci. Dlouhodobou tradici zde mají i zaměstnanecké fondy, které jsou garantovány kolektivními smlouvami. Př́íspěvky platí pouze zaměstnavatel a jsou daňově uznatelné. Zaměstnanecké fondy jsou vytváŕeny ve formě akciových společností a jsou vlastněny finančními institucemi, např. bankami a pojišt'ovnami.

Penzijní dávky vyplacené kombinací zaměstnaneckých fondů a státem garantované penze dosahují 
přibližně $70 \%$ hrubých př́ijmů dosahovaných před odchodem do důchodu.

\section{Důchodový systém v Německu}

Zásadní změny čekají i systém důchodového zabezpečení v Německu. Nadále zůstává zákonné důchodové pojištění se třemi oblastmi (pro pracovníky, pro zaměstnance a pojištění pro horníky) nejdůležitějším pilířem př́ijmů lidí ve stáŕí a zahrnuje cca $82 \%$ výdajů rozpočtu na důchodové pojišstění. Pojištění státních úředníků s celkovými výdaji představuje cca $13 \%$ důchodového rozpočtu.

Stále větší význam však získávají vedle toho zaměstnanecké důchodové systémy a soukromé připojištění. Různé formy soukromého pojištění jsou v Německu podporovány a více než $55 \%$ domácností má sjednáno životní pojištění. S tak zvaným di̊chodem podle Riestera, pojmenovaném podle dřívějšího ministra sociálních věcí Waltera Riestera, se zde nabízí daňově zvýhodněný model, který umožňuje zabezpečení na stáŕí formou soukromého kapitálového pojištění. Z důvodu nastolení sociální spravedlnosti mezi generacemi nedostávají př́jemci starobních důchodů momentálně žádnou valorizaci.

Výše př́íslušného důchodu závisí na výši příspěvků do důchodového pojištění a době tohoto pojištění. Důchod se počítá podle důchodové formule, která by měla zajistit po 45 letech pojištění cca $71 \%$ př́ijmů dosahovaných pred odchodem do důchodu.

Vládní strany rovněž schválily zvýšení zákonné hranice odchodu do důchodu z 65 let na 67 let. Mezi lety 2012 a 2035 se důchodová hranice bude postupně zvyšovat vždy o jeden měsíc. Zároveň byla vypracována Iniciativa 50 plus, která má pomoci zlepšit možnosti pracovních př́ležitostí pro starší občany (Wilke, 2009).

\section{Důchodový systém v Polsku}

Také Polsko provedlo reformu důchodového systému v roce 1998 z důvodu neudržitelného stavu průběžného státního důchodového systému. Polská vláda se proto rozhodla pro poměrně radikální reformu, kdy státní systém byl zjednodušen a převeden na systém tzv. notional defined contribution (NDC - průkopníkem tohoto systému se stalo Švédsko), který je navíc doplněný o soukromý penzijní fondový piliŕr. NDC má za cíl zavést do důchodového systému výraznější pojistný princip a umožnit větší flexibilitu věku pro odchod do důchodu. Každý občan má v systému NDC svůj účet, na kterém se vede evidence jeho príspěvků do důchodového systému. Ty bývají valorizovány jednou ročně podle rozhodnutí vlády. Na účtech však ve skutečnosti nejsou žádné prostředky a vláda si nevytváří žádné rezervy na budoucí výplaty důchodů. Dá se také ukázat, že systém NDC zůstává plně pod politickým vlivem, protože vláda může manipulovat $\mathrm{s}$ valorizačním mechanismem a se vzorcem, podle kterého se vypočítávají důchody. Nejvýraznější výhodou systému NDC je tak automatizace posunu věku pro odchod do důchodu podle demografického vývoje.

Přechod do nově zavedeného kombinovaného systému byl povinný pro všechny občany do 30 let a dobrovolný pro občany mladší 50 let. Do soukromě spravovaného fondového pilíre jde část odvodů (např. $10 \%$ mzdy), které spravuje více licencovaných (a regulovaných) penzijních fondů, většinou vlastněných zahraničními finančními institucemi (Commercial Union, AIG, Zürich, atd.) nebo polskými bankami. Takovým způsobem se zachovají jistoty dnešní starší generace a zároveň se vytváŕejí úspory pro financování důchodů dnešních mladších ročníků.

\section{Empirický výzkum}

V prosinci roku 2009 proběhlo sociologické šetření zkoumající problematiku českého důchodového systému. Na počátku výzkumu autoři formulovali následující hypotézy:

1) Více než $70 \%$ občanů starších 30 let nesouhlasí s posunutím hranice odchodu do důchodu a 60tiletou hranici považují za přijatelnou.

2) Většina občanů bez ohledu na věk a vzdělání (více než $60 \%$ ) je spokojena se stávajícími sazbami důchodového pojištění.

3) Většina občanů se základním a SŠ vzděláním (více než $60 \%$ ) má uzavřené důchodové připojištění a jejich príspěvek nepřesahuje $500 \mathrm{Kč}$ měsíčně.

4) U více než $70 \%$ občanů s VŠ vzděláním přesahuje příspěvek na důchodové připojištění 1000 Kč měsíčně.

5) Většina občanů bez ohledu na věk a vzdělání (více než $60 \%$ ) neslyšela o připravovaných změnách $\mathrm{v}$ důchodovém systému.

6) Většina občanů starších 30 let (více než $60 \%$ ) se domnívá, že starobní důchody by měly být spojeny s větší jistotou.

7) Více než $70 \%$ občanů bez ohledu na věk a vzdělání by přivítalo možnost přispívat více do prvního piliřre důchodového systému.

Cílem výzkumu bylo zjistit, jaké jsou aktuální postoje občanů $\mathrm{k}$ důchodové problematice a $\mathrm{zda}$ je veřejnost seznámena $\mathrm{s}$ připravovanými změnami v zájmové oblasti. Rovněž si výzkum kladl za cíl zjistit, jaké další investiční př́ležitosti jsou dnes v České republice využívány za účelem finančního zabezpečení ve stáríí. 
Výzkum byl proveden pomocí dotazníkového šetření. Dotazování bylo prováděno studenty Hornickogeologické fakulty formou prímého oslovování respondentů $\mathrm{v}$ některých částech Ostravy, konkrétně pak v centru na Masarykově náměstí, v Porubě na Alšově náměstí, na Dubině před hypermarketem Interspar, rovněž pak ve městě Opavě na Dolním náměstí a v Hlučíně na Mírovém náměstí. K potvrzení nebo vyvrácení našich hypotéz bylo osloveno 400 respondentů. Ke zpracování bylo následně předáno 367 dotazníků, což znamenalo návratnost takřka $92 \%$. V průběhu zpracování se ukázalo, že v 10 prípadech respondenti neodpověděli na všechny otázky. Dotazník obsahoval 17 otázek, přičemž prvních 5 otázek se zaměřovalo na osobnostní profil respondenta. U většiny otázek si respondenti mohli vybírat z nabízených variant odpovědí. Tři otázky byly dichotomické a dvě otázky byly zcela nestrukturované.

Při vyhodnocování se ukázalo, že většinu našich respondentů tvořily ženy a to z $60 \%$. Jaké bylo složení respondentů podle věku, naznačuje obrázek 1.

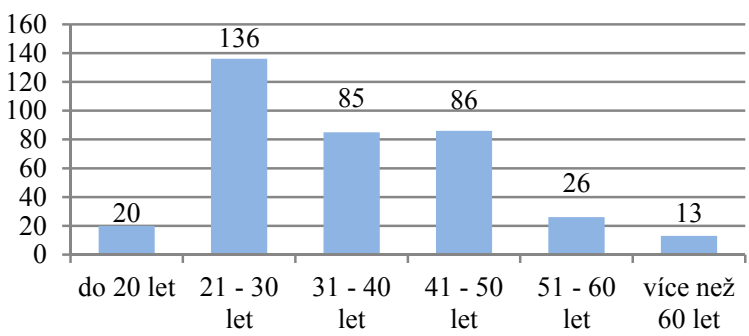

Obrázek 1 Věková struktura respondentů

Z hlediska vzdělání byla nejpočetnější skupina středoškolsky vzdělaných respondentů, kteří byli zastoupeni $68 \%$ (základní vzdělání $4 \%$, dosažené vysokoškolské vzdělání $28 \%$ ). Rozložení respondentů dle jejich př́jmů zobrazuje obrázek 2 , podle odvětví pak obrázek 3.

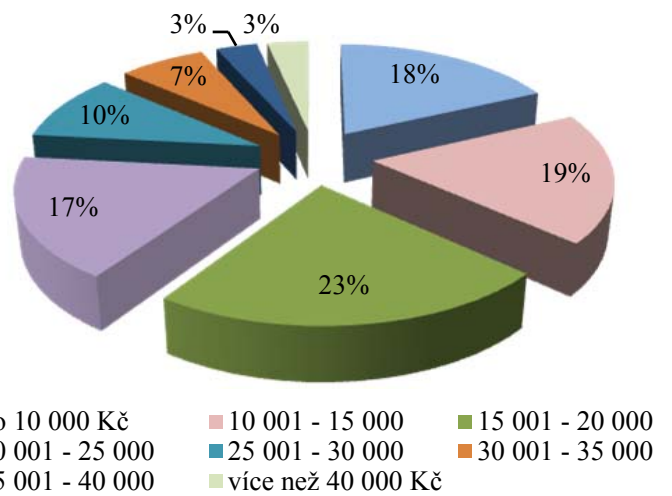

Obrázek 2 Rozložení respondentů podle hrubého měsíčního př́ijmu
Naši respondenti jsou ze $72 \%$ v zaměstnaneckém nebo obdobném poměru, $8 \%$ je osobou samostatně výdělečně činnou (OSVČ), 14 \% je studenty. Zbývajících $6 \%$ představují ti, kteří uvedli kombinaci zaměstaneckého poměru a OSVČ $(1 \%)$ a jiný stav - důchodce, nezaměstaný (5\%).

Dále již budou prezentovány samotné výsledky provedeného sociologického šetření. Výsledky byly podrobněji analyzovány $\mathrm{z}$ hlediska vzdělanostní a věkové struktury respondentů. $\mathrm{K}$ vzdělanostní struktuře musíme uvést, že malý počet dotázaných pouze se základním vzděláním (13 respondentů) nedává dostačující výpovídací schopnost $\mathrm{k}$ níže uvedeným zjišsěním. Údaje proto uvádíme orientačně a pro úplnost. První výzkumná otázka zjištovala souhlas s prodloužením hranice odchodu do důchodu ve věku 65 let. Odpovědi byly téměř jednoznačné, jak dokladují obrázky 4 a 5 . Z obou obrázků je zřejmé, že nesouhlas s posunem hranice odchodu do důchodu vyjádřilo více jak $75 \%$ dotázaných. U středoškoláků a respondentů mladších 51 let nesouhlas vyjádřilo dokonce $85 \% \mathrm{z}$ nich.

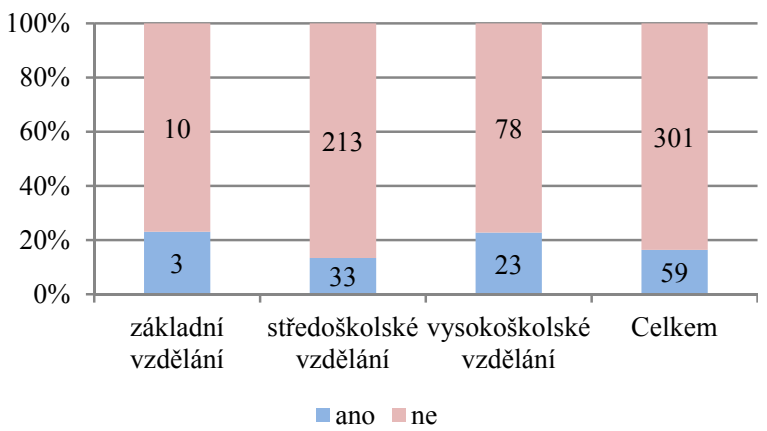

Obrázek 4 Souhlas s prodloužením hranice odchodu do důchodu podle vzdělání respondentů

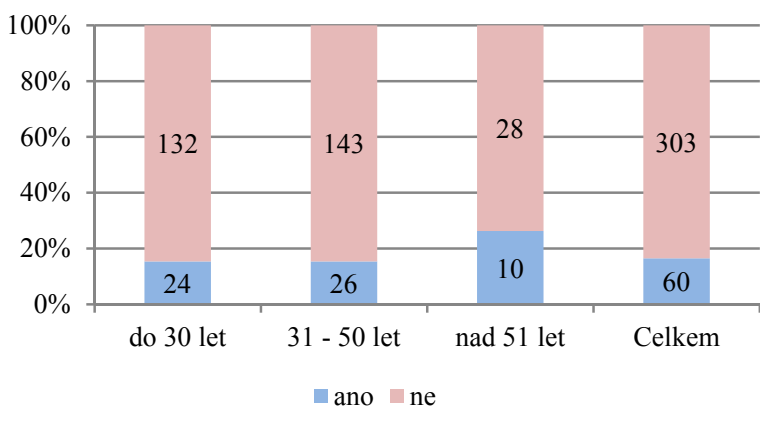

Obrázek 5 Souhlas s prodloužením hranice odchodu do důchodu podle věku respondentů

Obrázek 6 pak uvádí, jaká věková hranice pro odchod do důchodu je přijatelná pro nespokojené respondenty. Celkem jich bylo 297 (podle věku), resp. 295 (podle vzdělání).

Z obrázků 6 a 7 lze vypozorovat, že ani vzdělání a ani věk nerozhoduje o preferencích věku 60 let jako 


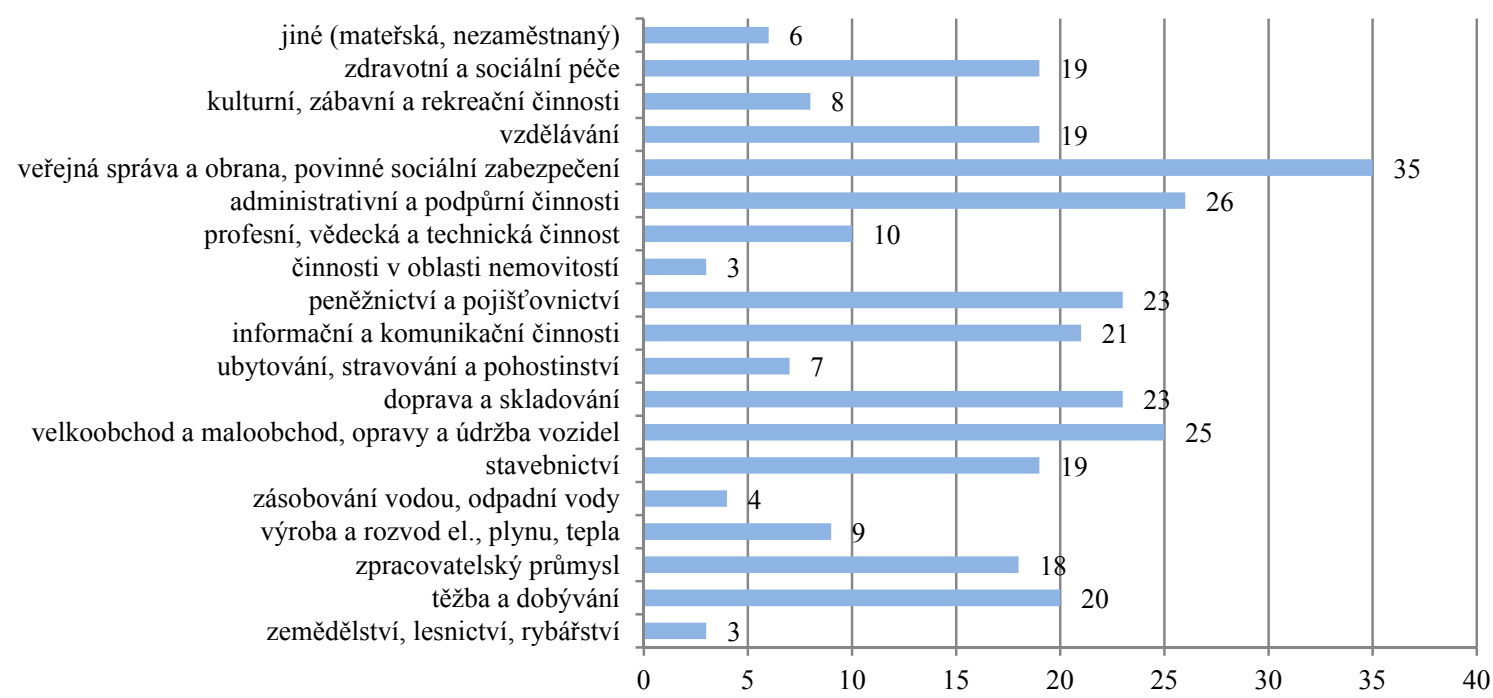

Obrázek 3 Zastoupení respondentů v odvětvích národního hospodářství

hraničního věku pro odchod do důchodu. Pro tuto věkovou hranici se vyjádřilo 182 respondentů, což představuje 61,07 \%. Prizmantem vzdělání pak středoškoláci preferují tuto věkovou hranici téměř $75 \%$. Stejnou představu pak mají i respondenti ve věku 30 - 50 let. Jako významější se též ukazaje volba 55 let věku. Dotázaní se základním vzděláním tuto hranici volili $\mathrm{z} \quad 15 \%$, středoškoláci $\mathrm{s} \quad 8 \quad \%$

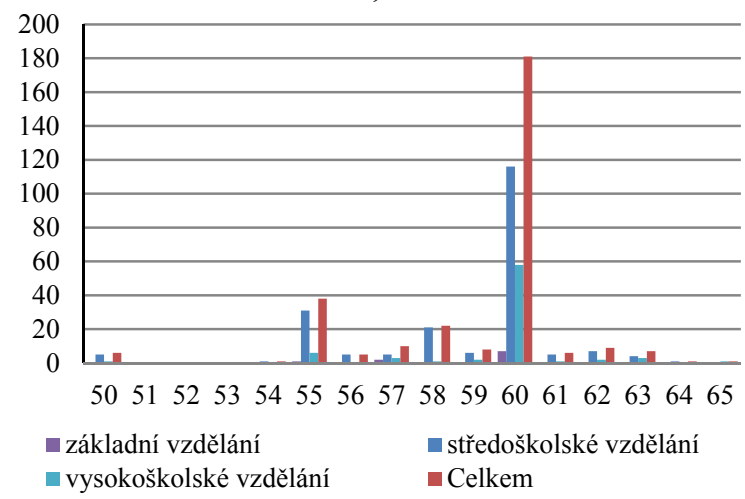

Obrázek 6 Přijatelná věková hranice pro odchod do důchodu podle vzdělání respondentů

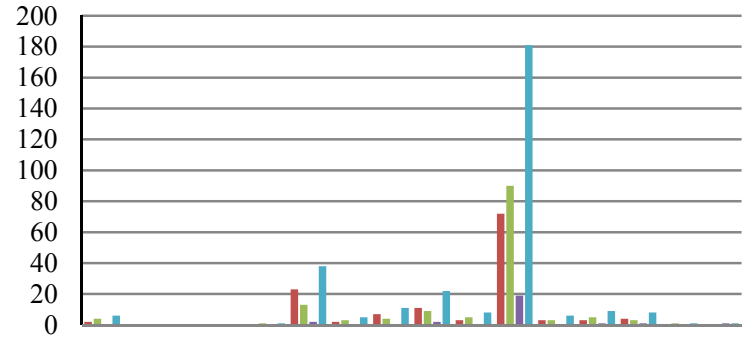

$\begin{array}{llllllllllllllll}50 & 51 & 52 & 53 & 54 & 55 & 56 & 57 & 58 & 59 & 60 & 61 & 62 & 63 & 64 & 65\end{array}$

$\square$ do 30 let $\square 31$ - 50 let $\square$ nad 51 let $\square$ Celkem

Obrázek 7 Přijatelná věková hranice pro odchod do důchodu podle věku respondentů a vysokoškoláci pak z $13 \%$. Z hlediska věku pak mladší 30 let preferovali 55 let věku z $18 \%$, ve věku 30 - 51 let z $8 \%$ a starší 51 let pak z $13 \%$.

Jak se oslovení vyjádřili $\mathrm{k}$ otázce spokojenosti se sazbou pojistného na státní důchodové pojištění, vidíme na další dvojici obrázků 8 a 9 .

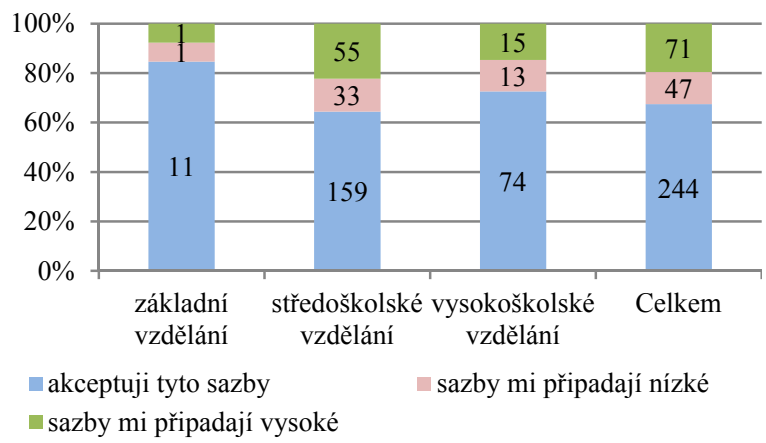

Obrázek 8 Spokojenost se stávajícími sazbami na státní důchodové pojištění podle vzdělání respondentů

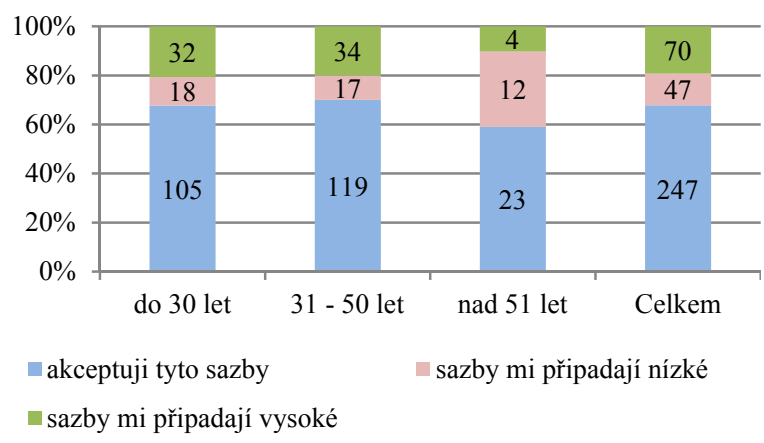

Obrázek 9 Spokojenost se stávajícími sazbami na státní důchodové pojištění podle věku respondentů

Sazby jsou přijatelné téměr̆ pro dvě třetiny respondentů $(68 \%)$. Př̀i podrobnější analýze zjistíme, že 
středoškolákům sazby připadají vysoké (20 \%) a starším 51 let naopak sazby připadají nízké (30\%). $\mathrm{V}$ prŕípadě, že dotázaný označil variantu odpovědi Sazby mi pripadají nízké, byl v následující otázce požádán, aby navrhl, na jakou úroveň by předmětnou sazbu zvýšil. Sazby pojistného připadaly nízké celkem $13 \%$ respondentů. Většina $\mathrm{z}$ nich však neuměla následně uvést, na jakou úroveň by tyto sazby zvýšili. Ojedinělé návrhy se týkaly zvýšení pojistného ze strany zaměstnance $\mathrm{v}$ rozpětí od 7 do $18 \%$, resp. pojistného ze strany zaměstnavatele $\mathrm{v}$ rozpětí od 23 do $30 \%$.

$\mathrm{Na}$ otázku, zda jsou respondenti účastníky dobrovolného penzijního připojištění, jich kladně odpovědělo $63 \%$. Zaměstnavatel potom na toto připojištění přispívá $46 \% \mathrm{z}$ nich. Podívejme se dále podrobněji na tuto otázku $\mathrm{z}$ hlediska vzdělání a věku dotázaných.

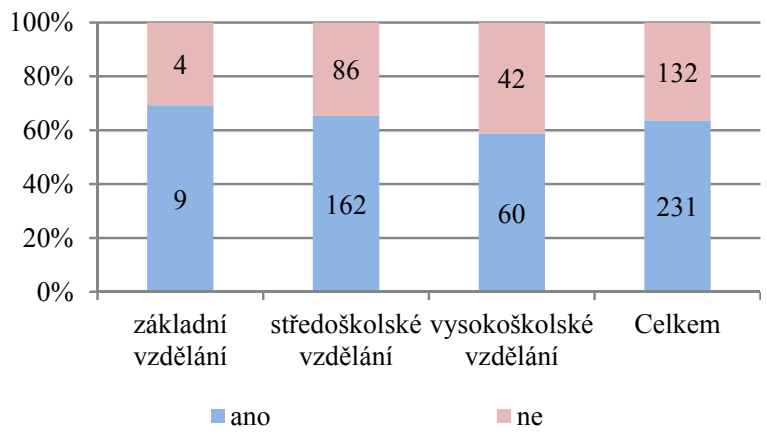

Obrázek 10 Účast $\mathrm{v}$ dobrovolném penzijním připojištění podle vzdělání respondentů

Z obrázku 10 je zřejmé, že vzdělání nemá významnější vliv na účast $\mathrm{v}$ dobrovolném penzijním připojištění. Mírný pokles, resp. vzestup cca $5 \%$ oproti středoškolákům zaznámenávají vysokoškoláci, resp. respondenti se základním vzděláním. Zato věk respondetů se zásadnějším způsobem odráží $\mathrm{v}$ dobrovolném připojištění. Zatímco dotazovaní do 30 let se účastní pouze z $50 \%$, ve věku 31 - 50 let pak ze $72 \%$, resp. $77 \%$ u respondetů starších 51 let (viz obrázek 11).

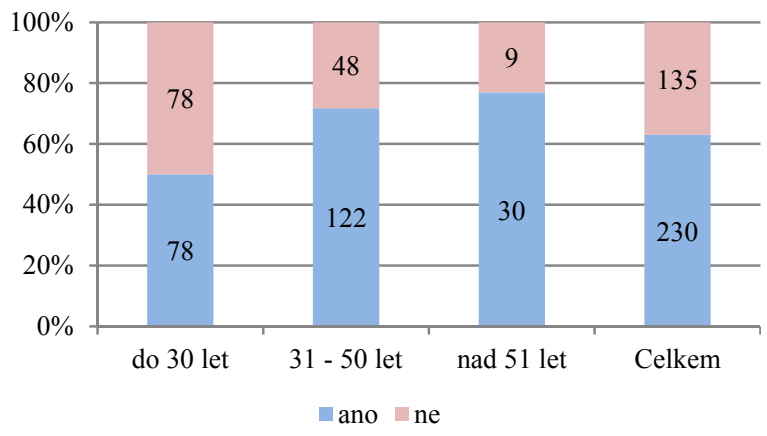

Obrázek 11 Účast v dobrovolném penzijním připojištění podle věku respondentů
Pro výši vyplacené penze $\mathrm{z}$ dobrovolného připojištění je rozhodující doba, po kterou je účastník připojištěn, a výše částky, kterou přispívá. Obrázky 12 a 13 zcela potvrzují zjištění Asociace penzijních fondů: okolo $70 \%$ účastníků penzijního připojištění přispívá částkou nepřesahující $500 \mathrm{Kč}$. Z hlediska vzdělanostní struktury dotázaných vybočují vysokoškoláci (65\%) a lidé se základním vzděláním (44\%). U respondentů se základním vzděláním však jejich celkový malý počet významně snižuje vypovídací schopnost, jak již bylo uvedeno výše $\mathrm{v}$ textu.

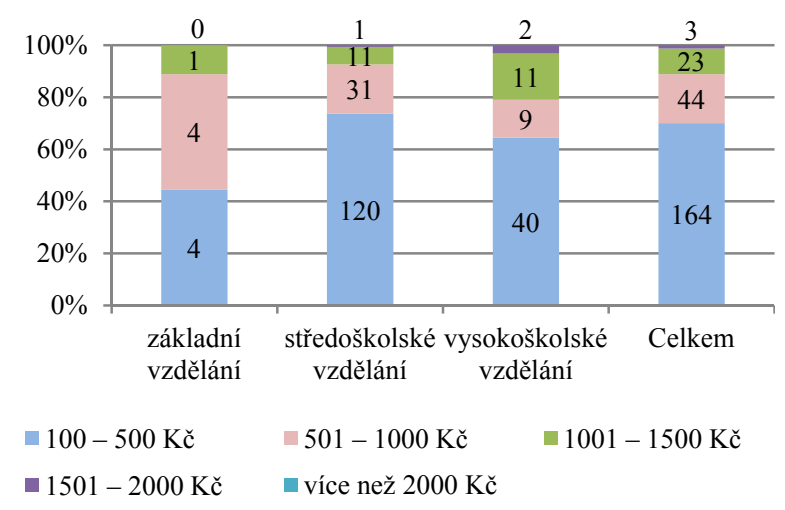

Obrázek 12 Měsíční př́íspěvek do penzijního připojištění podle vzdělání respondentů

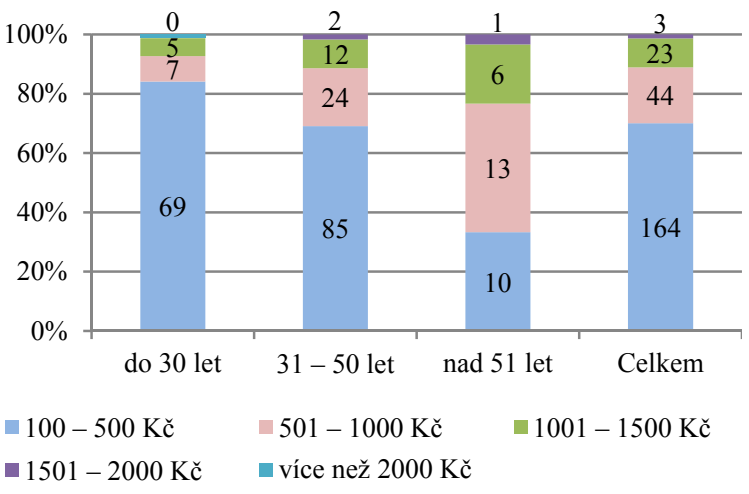

Obrázek 13 Měsíční př́ispěvek do penzijního připojištění podle věku respondentů

Jelikož v roce 2009 byly vládou připraveny změny $\mathrm{v}$ důchodovém systému, zajímalo nás, jaká je informovanost $\mathrm{v}$ této oblasti.

Jak můžeme vidět v obrázku 14 a 15 , informovanost o připravovaných změnách klesá $\mathrm{s}$ věkem a se vzděláním. Z šetření je zřejmé, že zájem o připravované změny je větší u stř̌edoškoláků než u vysokoškoláků a u kategorie 31-50 let než u starších 51 let. Pokud bychom uvažovali všechny dotázané, pak mírná většina respondentů $(53 \%)$ není o změnách informována vůbec. Menšina (47 \%) již o změnách ví, avšak pouze $5 \%$ dotázaných tyto změny podrobně studovalo. 


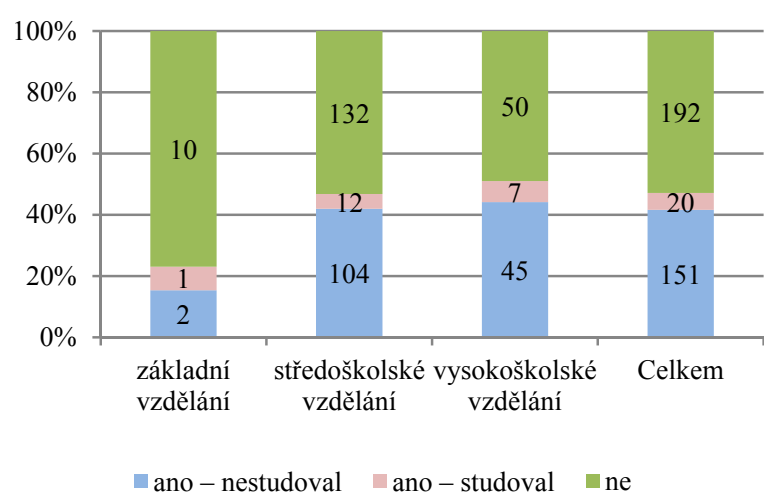

Obrázek 14 Informovanost o připravovaných změnách v penzijním připojištění podle vzdělání respondentů

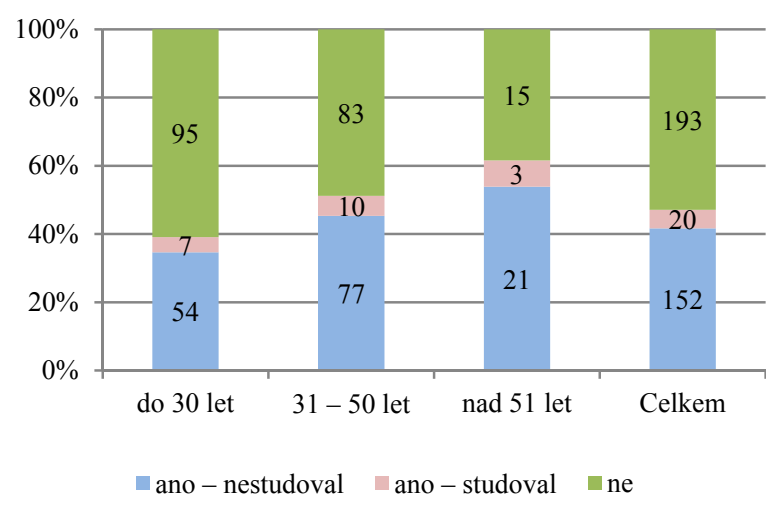

Obrázek 15 Informovanost o připravovaných změnách v penzijním připojištění podle věku respondentů

Zjištění týkající se vztahu dotázaných $\mathrm{k}$ riziku ve spojení se starobními důchody prokázalo, že v naprosté menšině jsou ti respondenti, kteří jsou přesvědčeni, že spoření na důchod může být spojeno $\mathrm{s}$ vyšši mírou rizika. Bez ohledu na věk a vzdělání se tak vyjádřilo pouze $10 \%$ dotázaných. Mírně v rozporu se zažitou představou se $\mathrm{k}$ riziku vyjádřili starší 51 let. Větší riziko by akceptovalo $18 \% \mathrm{z}$ nich. U vysokoškoláků též mírně narostl počet těch, kterým by nevadilo spoření na důchod $\mathrm{s}$ větším rizikem $(13 \%)$.

Předposlední otázka našeho dotazníku zjišt’ovala, jakou kombinaci z uvedených možností by uvítalo nejvíce dotázaných. Jednalo se o poměr státního a soukromého důchodového pilíře. Samotné zjištění prezentují obrázky 16 a 17.

Zde můžeme vidět, že nejvíce respondentů bez ohledu na vzdělání (základní - 46 \%, středoškolské $41 \%$, vysokoškolské $-36 \%$ ) by přispívalo méně penězi do státního důchodového pojištění a více do soukromého pilíře. Věk respondentů však již volbu ovlivnil, což je zřejmé z obrázku 17. Dotázaní do 50 let věku upřednostňují variantu, při které by přispívali méně penězi do státního důchodového pilíře a více penězi do pilí̌re soukromého (do 30 let $48 \%, 31-51$ let $36 \%$ ). Respondenti starší 51 let by naopak více prrispívali do státního důchodového pilíře (42\%).

Dobrovolné penzijní připojištění není jediným způsobem, jak zhodnocovat peněžní prostředky a spořit na důchod. Jaké další způsoby ukládání peněz jsou dnes využívány ze strany respondentů, zjišstovala poslední otázka našeho dotazníku, viz obrázky 18 a 19.

\begin{tabular}{|c|c|c|c|c|}
\hline Celkem & 94 & 71 & 144 & 48 \\
\hline $\begin{array}{l}\text { vysokoškolské } \\
\text { vzdělání }\end{array}$ & 29 & 25 & 37 & 10 \\
\hline $\begin{array}{l}\text { středoškolské } \\
\text { vzdělání }\end{array}$ & 61 & 45 & 101 & 36 \\
\hline základní vzdělání & 4 & 1 & 6 & 2 \\
\hline
\end{tabular}

- přispíval/a bych více penězi pouze do státního důchodového pojištění

- přispíval/a bych více penězi do státního důchodového pojištění a méně penězi do soukromého piliŕre

- přispíval/a bych méně penězi do státního důchodového pojištění a více penězi do soukromého pilíře

prrispíval/a bych více do obou piliríu

Obrázek 16 Volba přispívání do důchodových pilírư podle vzdělání respondentů

\begin{tabular}{|c|c|c|c|c|}
\hline \multirow{3}{*}{$\begin{array}{l}\text { vysokoškolské } \\
\text { vzdělání } \\
\text { středoškolské } \\
\text { vzdělání }\end{array}$} & 94 & 71 & 144 & 48 \\
\hline & 29 & 25 & 37 & 10 \\
\hline & 61 & 45 & 101 & 36 \\
\hline \multirow[t]{2}{*}{ základní vzdělání } & 4 & 1 & 6 & 2 \\
\hline & & & & $100 \%$ \\
\hline \multicolumn{5}{|c|}{$\begin{array}{l}\text { prrispíval/a bych více penězi pouze do státního důchodového } \\
\text { pojištění } \\
\text { přispíval/a bych více penězi do státního důchodového pojištění a } \\
\text { méně penězi do soukromého pilíŕe } \\
\text { - přispíval/a bych méně penězi do státního důchodového pojištění } \\
\text { a více penězi do soukromého pilíře } \\
\text { príspíval/a bych více do obou piliřru }\end{array}$} \\
\hline
\end{tabular}

Obrázek 17 Volba přispívání do důchodových pilíruo podle věku respondentů

Zcela dominující investiční příležitostí je stavební spoření, které je upřednostňováno bez ohledu na věk a vzdělání. Jak ukázalo naše šetření, celkem tuto možnost využivá více jak $33 \%$ dotázaných. $Z$ hlediska vzdělání pak se základním vzděláním $35 \%$, se středoškolským vzděláním $43 \%$ a s vysokoškolským vzděláním potom $38 \%$. Z hlediska věku potom mladší 30 let spoří $44 \%$, ve věku $31-50$ let $40 \%$ a starší 51 
let potom do stavebního spoření investují $33 \%$. Dalším významným produktem je životní pojištění, které má uzavřeno bez ohledu na věk a vzdělání celá čtvrtina dotázaných. Nemovitosti jako způsob ukládání peněz uvedlo potom $7 \%$ dotázaných. $\mathrm{Z}$ obou obrázků je též patrná významná skupina (cca $12 \%$ ), která nevyuživá žádný z uvedených způsobů zhodnocování peněžních prostředků.

\begin{tabular}{|c|c|c|c|c|c|}
\hline \multirow{3}{*}{$\begin{array}{l}\text { Celkem } \\
\text { vysokoškolské } \\
\text { vzdělání }\end{array}$} & 233 & 2716 & 139 & \multicolumn{2}{|c|}{2640869} \\
\hline & & \multirow[b]{2}{*}{96} & & \multirow{2}{*}{\multicolumn{2}{|c|}{$12 \quad 16217$}} \\
\hline & 67 & & 43 & & \\
\hline \multirow{2}{*}{$\begin{array}{l}\text { středoškolské } \\
\text { vzdělání } \\
\text { základní } \\
\text { vzdělání }\end{array}$} & 159 & 178 & 90 & \multicolumn{2}{|c|}{1424648} \\
\hline & 7 & 12 & 6 & 0 & 4 \\
\hline \multicolumn{2}{|c|}{$0 \%$} & $50 \%$ & & & $100 \%$ \\
\hline \multicolumn{2}{|c|}{$\begin{array}{l}\text { stavební spoření } \\
\text { akcie + dluhopisy } \\
\text { akermínované vklady } \\
\text { drahé kovy a kameny } \\
\text { jiné }\end{array}$} & \multicolumn{4}{|c|}{$\begin{array}{l}\text { — podílové fondy } \\
\text { životní pojišstění } \\
\text { —umělecké předměty } \\
\text { unemovitosti } \\
\text { žadný způsob }\end{array}$} \\
\hline
\end{tabular}

Obrázek 18 Další způsoby ukládání peněz podle vzdělání respondentů

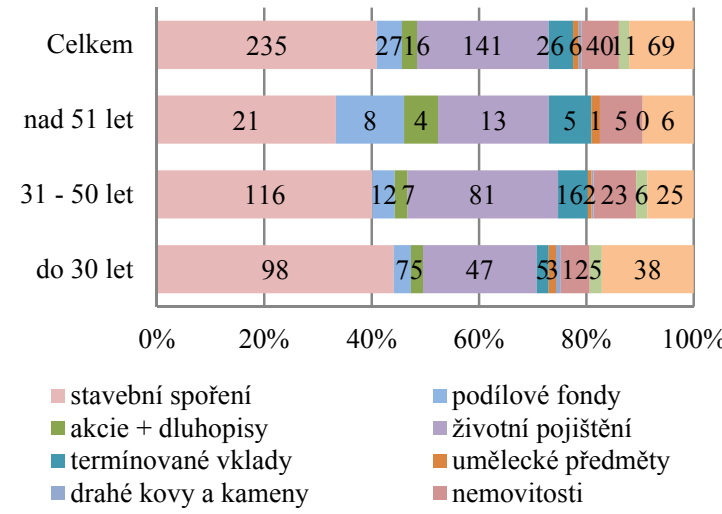

Obrázek 19 Další způsoby ukládání peněz podle věku respondentů

\subsection{Testování hypotéz}

Přijetí nebo zamítnutí hypotéz, které byly definovány na začátku našeho empirického výzkumu, provádíme pomocí testování hypotéz. $\mathrm{V}$ našem př́ípadě jsme uplatnili test hypotézy o relativní četnosti, při kterém testujeme hypotézu, že relativní četnost určité varianty znaku v základním souboru se rovná určitému číslu (viz Hindls a kol., 2002).

Nulová hypotéza tedy je:

$$
H_{0}: \pi=\pi_{0} .
$$

Alternativní hypotéza byla uvažována následující:

$$
H_{1}: \pi>\pi_{0} .
$$

Jako testové kritérium jsme použili následující statistiku (viz Hindls a kol., 2002):

$$
U=\frac{p-\pi_{0}}{\sqrt{\frac{\pi_{0\left(1-\pi_{0}\right)}}{n}}} .
$$

Uvedené testové kritérium má při platnosti $H_{0}$ asymptoticky normované normální rozdělení, přičemž $p$ je výběrová relativní četnost (Činnosti Evropské unie - Zaměstnanost a sociální věci, 2009). Byla zvolena obvyklá hladina významnosti $\alpha=0,05$. Pro alternativní hypotézu je kritický obor vymezen následovně:

$$
U \geq 1,645 .
$$

Jak dopadlo vlastní testování hypotéz, zobrazuje tabulka 3.

Shrneme-li výsledky našeho výzkumu, lze konstatovat, že čtyři ze sedmi námi definovaných hypotéz byly prijaty a tři pak zamítnuty.

1) Více než $70 \%$ občanů starších 30 let nesouhlasí s posunutím hranice odchodu do důchodu a 60tiletou hranici považují za přijatelnou. Hypotéza prijata.

Tabulka 3 Testování hypotéz empirického výzkumu

\begin{tabular}{|l|c|c|c|c|c|c|c|}
\hline Testovaná hypotéza & $\mathbf{1}$ & $\mathbf{2}$ & $\mathbf{3}$ & $\mathbf{4}$ & $\mathbf{5}$ & $\mathbf{6}$ & $\mathbf{7}$ \\
\hline Počet respondentů & 207 & 365 & 172 & 172 & 366 & 209 & 360 \\
\hline Počet vyhovující & 171 & 247 & 124 & 13 & 193 & 189 & 95 \\
\hline Výběrová rel. četnost $p$ & 0,826 & 0,677 & 0,721 & 0,076 & 0,527 & 0,904 & 0,264 \\
\hline$H_{0}$ & 0,7 & 0,6 & 0,6 & 0,7 & 0,6 & 0,6 & 0,7 \\
\hline$H_{1}>$ & 0,7 & 0,6 & 0,6 & 0,7 & 0,6 & 0,6 & 0,7 \\
\hline Testové kritérium & 3,959 & 2,992 & 3,237 & $-17,870$ & $-2,838$ & 8,980 & $-18,057$ \\
\hline Kritický obor pro $\alpha=0,05$ & 1,645 & 1,645 & 1,645 & 1,645 & 1,645 & 1,645 & 1,645 \\
\hline Vyhodnocení & $\begin{array}{c}\text { Přijímáme } \\
\text { hypotézu } H_{1}\end{array}$ & $\begin{array}{c}\text { Přijímáme } \\
\text { hypotézu } H_{1}\end{array}$ & $\begin{array}{c}\text { Přijímáme } \\
\text { hypotézu } H_{1}\end{array}$ & $\begin{array}{c}\text { Zamítáme } \\
\text { hypotézu } H_{1}\end{array}$ & $\begin{array}{c}\text { Zamítáme } \\
\text { hypotézu } H_{1}\end{array}$ & $\begin{array}{c}\text { Přijímáme } \\
\text { hypotézu } H_{1}\end{array}$ & $\begin{array}{c}\text { Zamítáme } \\
\text { hypotézu } H_{1}\end{array}$ \\
\hline
\end{tabular}

Zdroj: Vlastní zpracování 
2) Většina občanů bez ohledu na věk a vzdělání (více než $60 \%$ ) je spokojena se stávajícími sazbami důchodového pojištění. Hypotéza prijata.

3) Většina občanů se základním a SŠ vzděláním (více než $60 \%$ ) má uzavřené důchodové připojištění a jejich př́spěvek nepřesahuje 500 Kč měsíčně. Hypotéza prijata.

4) U více než $70 \%$ občanů s VŠ vzděláním přesahuje příspěvek na důchodové připojištění 1000 Kč měsíčně. Hypotéza zamitnuta.

5) Většina občanů bez ohledu na věk a vzdělání (více než $60 \%$ ) neslyšela o připravovaných změnách $\mathrm{v}$ důchodovém systému. Hypotéza zamitnuta.

6) Většina občanů starších 30 let (více než 60 \%) se domnívá, že starobní důchody by měly být spojeny s větší jistotou. Hypotéza přijata.

7) Více než $70 \%$ občanů bez ohledu na věk a vzdělání by přivítalo možnost přispívat více do prvního pilíře důchodového systému. Hypotéza zamitnuta.

\subsection{Diskuze}

Většina dotázaných by raději přispívala méně penězi do státního důchodového pojištění a více penězi do soukromého pilíree, což jsme na počátku nepředpokládali. Vezmeme-li však v úvahu, že naprostá většina respondentů (cca $90 \%$ ) by preferovala $\mathrm{v}$ oblasti důchodů jistotu, je tento výsledek $\mathrm{v}$ jistém rozporu. $\mathrm{Na}$ jedné straně jsou lidé ochotni vložit více prostředkủ do soukromého pilíre, avšak na straně druhé preferují právě jistotu. Je sice pravdou, že i přes absenci státní garance za vklady na penzijním připojištění stávající pravidla a regulace neumožňují, aby střadatelé o své úspory přišli. Navrhované reformní kroky však do budoucna předpokládají uvolnění těchto pravidel a tím i zvýšení rizika pro účastníky penzijního spoření. I v prrípadě spoření na penzi je však nutno neopomenout tzv. zlaté investorské pravidlo, které říká, že čím vyšší výnosy, tím je větší riziko.

Další skutečnost, a to že veřejnost neakceptuje vyšší hranici odchodu důchodu, je pochopitelná. Je sice pravdou, že zvýšení této hranice je relativně snadná parametrická změna důchodového systému. Konec konců v novodobé historii ČR již byla provedena dvakrát, a sice $\mathrm{v}$ roce 1995 a 2009. Je obecně známo, že ve vyspělé západní Evropě je tato hranice vyšší než v ČR. Domníváme se, že další zvyšování hranice odchodu do důchodu nad 65 let bude již problematické. Jen stěží lze např́iklad očekávat, že tyto změny budou akceptovány pracovníky např. těžkého průmyslu. Také je pravdou, že se zvyšujícím se věkem nalézají starší pracovníci uplatnění stále obtížněji.
Další úskalí navrhované důchodové reformy spatřjueme v absenci zdrojů na vlastní důchodové spoření. Jak z našeho šetření vyplynulo, nejběžnější př́íspěvek na penzijní připojištění je 500 Kč, což potvrzují i údaje Asociace penzijních fondů. V roce 2008 činil průměrný měsíční př́íspěvek účastníků penzijního připojištění $450 \mathrm{Kč}$, což bylo stejně jako předloni. Výše př́spěvků klientů penzijních fondů není podle prezidenta Asociace penzijních fondů Jiřího Rusnoka uspokojivá. Pohybuje se kolem dvou procent průměrné hrubé mzdy a nemůže tak prý výrazněji vyrovnat pokles př́ijmu při odchodu do důchodu. Uvádí se, že na důchody bychom si měli šetřit kolem $10 \%$ př́jmu. Vzhledem $\mathrm{k}$ tomu, že $\mathrm{v}$ roce 2006 spořily domácnosti kolem $5 \%$ svých př́imů, je otázka zdrojů klíčová. Zvláště uvědomíme-li si, že $65 \%$ pracovníků dnes nedosahuje ani částek průměrné mzdy.

Záměr autorů důchodové reformy posílit druhý pilíř systému je zcela legitimní a nepochybně i nutný, avšak dle ekonomických ukazatelů je již v současné době pro většinu domácností nereálný. Díky uplatnění strategie opt-out mohou přibýt určité zdroje, domníváme se však, že i přesto bude velká většina domácností schopna spořit na svou penzi $\mathrm{v}$ řádu stokorun (nikoliv tisíců), což bude logicky znamenat, že nemohou počítat $\mathrm{s}$ pokrytím snížených př́imů $\mathrm{z}$ prvního pilíře důchodového systému. Pro úplnost dodejme, že při hodnocení výnosů $\mathrm{z}$ investic bychom neměli opomenout též inflační vlivy. Je sice pravdou, že v roce 2009 byla výše inflace prŕznivá $(1,0 \%)$, avšak v roce 2008 činila podle údajů ČSÚ $6,3 \%$. Z článku uveřejněného na portálu ihned.cz dne 26. 3. 2009 vyplývá, že zhodnocení prostředků za celý trh penzijního připojištění v roce 2008 činí neuvěřitelně nízkých $0,4 \%$ p.a. Příčiny jsou zcela jasné, ovšem i ve finančně prríhodnějších letech bude inflace ukrajovat z výnosů uskutečněných investic.

Podoba důchodového systému i jeho parametry jsou výsledkem politických rozhodnutí. Je mimo jakoukoli pochybnost, že nepř́znivý demografický vývoj nemůže stávající systém zachovat dlouhodobě stabilní. Nabízí se následující prŕístupy k řešení problému:

1) Nedělat nic.

2) Realizovat opatření na výdajové straně důchodového systému.

3) Realizovat opatření na př́ijmové straně důchodového systému.

4) Kombinace opatření na výdajové a př́ijmové straně.

Ačkoliv navrhovaná a realizovaná opatření se jeví jako opatření kombinující prŕjmovou i výdajovou stranu důchodového systému, ve skutečnosti se jedná o kroky zaměřující se především na stranu výdajovou. 
Zdá se, jako by správce důchodového systému rezignoval na stimuly, jež by zvrátily nepř́znivý demografický vývoj. Důvodem rezignace může být ta skutečnost, že stárnutí populace není fenoménem ČR, ale i dalších vyspělých států Evropy. Reformní kroky tak mají spíše restriktivní charakter. Zvýšením hranice odchodu do důchodu na 65 let zřejmě dojde $\mathrm{k}$ určité stabilizaci systému, avšak nebude-li provedena radikální změna také na straně př́ijmů, bude v budoucnu nezbytná další úprava věkové hranice směrem nahoru. Jak jsme uvedli výše v textu, opětovné zvyšování věku pro odchod do důchodu vidíme v českých podmínkách jako problematické, byt' hranice 65 let není v evropském kontextu nijak ojedinělou.

Jsme tedy přesvědčeni, že by bylo chybou upírat pozornost pouze jedním směrem, a proto nabízíme dále širší paletu námětů, $\mathrm{z}$ nichž by mohly vzejít konkrétní reformní kroky.

Stávající důchodový systém je rigidní, a proto navrhujeme jeho větši flexibilitu. Z našeho výzkumu vyplynulo, že většina respondentů by spíše více spořila na důchod v soukromém piliřii, ale téměř $27 \%$ dotázaných by naopak více přispívalo pouze do státního pilíře. Jsme proto přesvědčeni, že by mohlo být zajímavé, aby se občan mohl dobrovolně rozhodnout, jak velkou částku nad státem stanovené pojištěni ještě do důchodového systému vloží a do jakého pilíře. Přispíval-li by občan více do státního pilíře, jako protihodnotu by získal garanci vyššího důchodu např. o 5, 10,15, $20 \%$ nad standard v závislosti na výši pojistného. Pokud by občan toužil po větším důchodu, ale s vyšším rizikem, mohl by uplatnit přistup opt-out. Nutno pro úplnost dodat, že ani státní piliřr není úplně bez rizika, nebot' i stát může vyhlásit bankrot ${ }^{4}$.

Další opatření by mohlo mít např́íklad formu slevy na dani z př́imu nebo ještě lépe slevy na sociálním (důchodovém) pojištěni pro ty rodiče, kteří přivedou na svět více dětí. Odborná veřejnost však v této otázce není jednotná. Např. Holub uvádí: V Evropě je myšlenka zohlednění počtu vychovávaných dèti (tzv. koncept $C P A Y G)$ ve výši výsledné dávky diskutována již od 80. let. Zastánci tohoto konceptu vycházi $z$ tradičního pojetí rodiny, $k d y$ poř́zení dětí a jejich výchova je jednou z forem zabezpečeni na stárí, resp. pořizení ditěte je chápáno jako investice. Z ekonomického hlediska je však toto pojetí velmi problematické, $i$ když by se investični náklady vymezily pouze na náklady do vzdélání. Ty totiž nemusí nic vypovídat o využití tohoto vzdělání na pracovním trhu,

\footnotetext{
${ }^{4}$ Argentina vyhlásila v roce 2001 bankrot. Na počátku října 2008 stál Island na pokraji státního bankrotu. V prvních pěti měsících roku 2010 byl bankrot Řecka reálnou hrozbou.
}

kde se formuje odměna zaměstnance, která je pak základem pro placeni príspěvkü.

Jinou cestou, jak ocenit prínos ditéte pro di̊chodový systém, je stanoveni jeho hodnoty podle skutečně zaplacených př́spěvků, což je opět velmi problematické. Jaké budou di̊chodové nároky těch, jejichž děti nebudou z nejrůznějšich důvodů platit pojistné? Co dèti invalidní? A co nároky bezdětných lidi?

Dalši problém představuje otevřený pracovni trh $\check{C} R$ v rámci EU. Podobně jako tvrzení, že není možné zaručit, aby se z vychovávaného ditěte jednou stal plátce pojistného, nelze dále zaručit, že toto dítě bude plátcem pojistného $v \check{C} R$.

Vychovávané ditě jakožto predpokládaný budoucí príspěvek do di̊chodového systému a budoucího plátce pojistného jakožto skutečného prispěvatele do systému proto neni prakticky možné ztotožnit (Holub a kol., 2009).

S výše uvedeným se lze ztotožnit, avšak domníváme se, že stabilita průběžného důchodového systému především závisí na peněžních tocích. Pokud peněžní výdaje nebudou dostatečně kryty peněžními př́ijmy, hrozí další restriktivní opatření, jež se budou dotýkat většiny obyvatelstva. K oddálení, resp. zmírnění těchto restrikcí $\mathrm{v}$ budoucnu by mohla pomoci opatření na př́jjmové straně průběžného důchodového systému, resp. prvního pilíře. Nemá-li dojít k plošnému zvýšení pojistného, resp. důchodové daně, nezbývá než se zaměřit na zvýšení počtu přispěvatelů do systému. K tomu by mohla přispět propracovanější rodinná politika státu. Je však nezbytné, aby konkrétní opatření byla dále technicky dopracována. Jinak hrozí jejich zneužívání především ze strany sociálně nepřizpůsobivých občanů.

Stát, resp. obce mohou přispět ke kladnému rozhodnutí budoucích rodičů rozšírít rodinu i tím, že bude existovat funkční a dostupná infrastruktura (školky, školy, zdravotní péče, dopravní obslužnost, atd.)

Jak se dívají zaměstnavatelé na ženy, které si často berou paragraf, dovolenou, náhradní volno, aby mohly pečovat o své děti? Čím dál častěji se mluví o sociálni zodpovědnosti firem. Neměla by se tato zodpovědnost projevit i $\mathrm{k}$ zaměstnancům, kteří jsou zároveň rodiči? Jsme přesvědčeni, že zaměstnanecké (tzv. firemní) mateřské školky by jistě mnoho rodičů ocenilo. Úspěšné projekty zahraničních i domácích firem (např. Raiffeisen Bank, a.s, LINET, spol. s r.o.) $\mathrm{v}$ této oblasti mohou být inspirací i pro další podniky a instituce.

Můžeme pouze spekulovat o zvýšení porodnosti $\mathrm{v}$ budoucích obdobích. Je logické, že přivedení potomka na svět se u většiny domácností projeví spíše atakem na úspory než na jejich vytváření či zvyšování. Navíc je pochopitelné, že $\mathrm{v}$ průběhu produktivního 
života není schopnost generovat úspory stejná, což souvisí i s prioritami, které rodina musí řešit. V současnosti máme na mysli především otázku bydlení.

Pravdou je, že velká část př́ijmů domácností je dnes vynakládána na spotřební daň $\mathrm{v}$ podobě nákupu alkoholických nápojů a tabákových výrobků. Nechceme př́liš moralizovat, avšak vztah domácností (občanů) ke spoření na důchod by měl být především otázkou osobnich priorit a společenské odpovédnosti jedince. Př́i současné úrovni př́ijmů však většina občanů nebude schopna spořit na důchody významně více, než je tomu dnes.

V rozhovoru pro deník Právo dne 16. 5. 2009 Miroslav Kalousek uvádí, cituji: Systém, ze kterého čerpaji dnešni di̊chodci, ale nemůže donekonečna zajistit jednotlivým generacim zhruba 40 procent hrubé mzdy. Pro dnešni třicátníky budou penze z průběžného systému nižši, to je fakt, s tím nic neudèlá ani levice, ani pravicová rétorika. Penzijní reforma neni o ničem jiném, než že dnešní generace třicátníků a mladšich dostane jakousi nepríliš radostnou informaci, že z průběžného systému bude mít nižši důchody, než mají dnešní penzisté. Současný průběžný systém nemůže být ale nikdy zrušen, to je právě základ té mezigeneračni solidarity, z něj budou dnes ekonomicky aktivní mladé generace ale dostávat stále méně a ménè. Chcete-li mít penze vyšší, musite si celý život odkládat ze své spotřeby na svioj di̊chod. A stát vám nabizi různé možnosti, jak si na penzi naspořit. To je penzijní reforma (Kalousek, 2009).

Z výše uvedeného je nepochybné, že spořit na penzi se stane nutností. Dnešní tř̌icátníci, kteří si již spoří na penzi $\mathrm{v}$ rámci penzijního připojištění, se budou muset vyrovnat se skutečností, že jimi naspořená penze nepřilepší $\mathrm{k}$ dnešním 40 procentům hrubé mzdy, nýbrž pomůže pouze snížit avizovaný propad starobního důchodu vypláceného $\mathrm{z}$ průběžného pilíŕe důchodového systému.

$\mathrm{Z}$ našeho šetření jednoznačně vyplynulo, že problematika penzí by měla být spojena $\mathrm{s}$ jistotou. V současné době, a zřejmě tomu nebude ani $\mathrm{v}$ budoucnu jinak, máme jedinou jistotu, že to, co platí dnes, nemusí platit zítra. Žijeme v dobách nejistoty, a to je fakt, se kterým je nutno se vyrovnat a racionálně pracovat. Výsledkem by měla být jednoznačná diverzifikace úspor. Mnozí občané se navíc domnívají, že důchodu se ani nedožijí, a proto není potřeba se otázkou spoření na penzi vůbec zabývat. Ale i tento postoj je v konečném důsledku velmi zavádějící. Jsme proto přesvědčeni, že významnou podporou jakékoli podoby penzijní reformy je propracovaná výchova a osvěta široké veřejnosti. Skutečnost, že $53 \%$ respondentů není informováno o penzijní reformě, je smutným dokladem toho, že je tato otázka podceňována.

\section{Závěr}

Nelze očekávat, že demografický vývoj populace České republiky se bude významně lišit od vývoje v jiných státech EU, což se negativně projevuje na stabilitě důchodového systému, a proto je jeho reforma naprosto nevyhnutelná. $\mathrm{V}$ tomto článku byly shrnuty dosavadní reformní kroky v ČR a sousedních státech. Článek přinesl také výsledky sociologického šetření. Z něho vyplynulo, že bez ohledu na věk a vzdělání $61 \%$ respondentů by pro odchod do důchodu volilo věk 60 let. Pro $68 \%$ dotázaných jsou sazby na státní důchodové pojištění príijatelné. Většina občanů je účastníkem dobrovolného penzijního připojišstění $(63 \%)$ a $46 \%$ z nich potom zaměstnavatel na toto připojištění přispívá. Výzkum potvrdil skutečnost, že většina účastníků penzijního připojištění příspívá částkou nepresahující 500 Kč (70 \%). Výzkum rovněž ukázal, že většina (53\%) není o změnách $\mathrm{v}$ důchodovém systému informována a pouze $5 \%$ navrhované změny podrobně studovalo. Pouze $10 \%$ respondentů je přesvědčeno, že je vhodné, aby spoření na důchod bylo spojeno $\mathrm{s}$ vyšší mírou rizika. Z šetření dále vyplynulo, že $40 \%$ dotázaných by přispívalo méně penězi do státního důchodového pojištění a více do soukromého pilíře. Kromě penzijního připojištění občané dále nejvíce využívají formu stavebního spoření (41 \%). Životní pojištění má uzavřeno $25 \% \mathrm{z}$ nich. Údaje byly podrobně analyzovány $\mathrm{z}$ hlediska věku a vzdělání respondentů.

V úvahách o budoucí podobě penzijní reformy bylo autory př́spěvku uvedeno několik námětů $\mathrm{k}$ diskuzi. Jednalo se zejména o požadavek větší flexibility důchodového systému, odměňování (motivování) rodičů formou slevy na dani z př́jmu, resp. slevy na sociálním (důchodovém) pojištění, posilování sociální zodpovědnosti firem a rozvoj firemních mateřských školek, zahájení propracované výchovy a osvěty široké veřejnosti a především vedení občanů $\mathrm{k}$ větši individuální odpovědnosti.

\section{Literatura}

HINDLS, R., HRONOVÁ, S., SEGER, J. (2002). Statistika pro ekonomy. 1. vydání. Praha: Professional Publishing.

WILKE, Ch.B. (2009). German Pension Reform, On Road Towards a Sustainable Multi-Pillar System. Frankfurt: Peter Lang Verlag. 


\section{Další zdroje}

APF Průměrný príspěvek na penzi zůstal loni na 450 Kč [online]. FinančníNoviny.cz, (2009). [cit. 2009-09-15]. Dostupný z WWW: <http://www. financninoviny.cz/zpravy/apf-prumerny-prispevek-napenzi-zustal-loni-na-450-kc/377555\&id_seznam $=382$ $>$.

Bezděkova komise II: Změňte penze! [online]. www.lidovky.cz, (2010) [cit. 2010-04-30]. Dostupný z WWW: <http://www.lidovky.cz/bezdekova-komiseii-zmente-penze-d4f-/ln_noviny.asp? $=$ A100121_000 $060 \_$ln_noviny_sko\&klic $=235166 \&$ mes $=100121 \_0>$. Činnosti Evropské unie - Zaměstnanost a sociální věci [online]. Europa, (2009) [cit. 2009-12-10]. Dostupný z WWW: <http://europa.eu/pol/socio/index_cs.htm >. ČSÚ (2009). Statistická ročenka České republiky 2008 - 4. Obyvatelstvo [online]. [cit. 2010-01-08]. Dostupný z WWW: <http://www.czso.cz/csu/2008 edicniplan.nsf/kapitola/0001-08-2008-0400>.

ČSÚ (2000). Porodnost a plodnost - Úhrnná plodnost [online]. [cit. 2010-01-08]. Dostupný z WWW: $<$ http://www.czso.cz/csu/2001 edicniplan.nsf/o/400801-1993_2000-uhrnna_plodnost $>$.

Důchodová reforma [online]. Fakta o Německu [cit. 2010-01-04]. Dostupný z WWW: <http://www.tatsa chen-ueber-deutschland.de/cz/spoleenost/main-content -08/duchodova-reforma.html>.

Důchodové systémy ve světě [online]. Finance.cz [cit. 2010-01-09]. Dostupný z WWW: <http://www.finan ce.cz/duchody-a-penze/informace/duchodovy-system/ zahranici/s.

Důchody v Evropské unii [online]. Měšec.cz, (2004) [cit. 2009-11-15]. Dostupný z WWW: <http://www. mesec.cz/clanky/duchody-v-evropske-unii/>.

Evropská komise (2009). Intergenerational solidarity Analytical report [online]. [cit. 2009-12-12]. Dostupný z WWW: <http://ec.europa.eu/public_opinion/ flash/fl_269_en.pdf>.

HOLUB, M. a kol. (2009). Pružné formy podpory rodin s dětmi v sociálním pojištěni [online]. Ministerstvo práce a sociálních věcí, [cit. 2010-04-27]. Dostupný z WWW: <http://www.mpsv.cz/files/clanky/ 7765/Pruzne_formy_podpory.pdf $>$.

KALOUSEK, M. (2009). Paroubek by si měl prestat hrát na opozici, v žádné neni [online]. KDU-ČSL, [cit. 2009-09-02]. Dostupný z WWW: <http://www.kdu. $\mathrm{cz} /$ default.asp?page $=311 \& \mathrm{idr}=132 \& \mathrm{IDCl}=27858>$.

Kličem ke stárnutí je mezigeneračni solidarita [online]. Europa, 2009 [cit. 2009-12-12]. Dostupný z WWW: <http://ec.europa.eu/ceskarepublika/press/ press_releases/09651_cs.htm>.
Ministerstvo financí České republiky (2009). Legislativa doplňkového di̊chodového systému [online]. [cit. 2009-09-10]. Dostupný z WWW: <http://www.mfcr. $\mathrm{cz} / \mathrm{cps} / \mathrm{rde} / \mathrm{xchg} / \mathrm{mfcr} / \mathrm{xsl} / \mathrm{ft}$ leg_ppap.html .

Ministerstvo práce a sociálních věcí (2009a). Di̊chodové pojištěni [online]. MPSV.CZ, [cit. 2009-12-20]. Dostupný z WWW: <http://www.mpsv. cz/cs/3>.

Ministerstvo práce a sociálních věcí (2009b). Životní a existenčni minimum [online]. [cit. 2009-09-10]. Dostupný z WWW: <http://www.mpsv.cz/cs/3213>.

Ministerstvo práce a sociálních věcí (2005). Závěrečná zpráva [online]. MPSV.CZ, [cit. 2010-01-05]. Dostupný z WWW: <http://www.mpsv.cz/files/ clanky/2235/zaverecna_zprava.pdf $>$.

Ministerstvo práce a sociálních věcí (2004). 80 let sociálního pojištěni [online]. [cit. 2010-04-27]. Dostupný z WWW: <http://www.cssz.cz/NR/rdonlyres/ 5572A3BE-22CD-46D3-A31F-2BA0076C1C63/0/ publikace_80letSP.pdf $>$.

Partner News: Aj tretí pilier čakajú zmeny [online]. Investujeme.sk, 2009, [cit. 2010-01-10]. Dostupný z WWW: <http://www.investujeme.sk/kratke-zpravy/ partners-news-aj-treti-pilier-cakaju-zmeny/>.

Piliere dochodkového systému [online]. O peniazoch [cit. 2010-01-10]. Dostupný z WWW: www: $<$ http://openiazoch.zoznam.sk/produkty/ds/piliere.asp $>$.

Prvý, druhý a tretí pilier [online]. Finance, 2010, [cit. 2010-01-10]. Dostupný z WWW: <http://www. finance.sk/dochodok/informacie/dochodkovy-systemna-sr/prvy-druhy-treti-pilier>.

Schodek na účtu, ze kterého se vypláceji důchody a nemocenské, narůstá. Po prvním čtvrtletí na něm chybi 10,4 miliardy korun [online]. Domaci.iHNed.cz, 2010 [cit. 2010-04-30]. Dostupný z WWW: $<$ http://domaci.ihned.cz/c1-42824440-duchodovyucet-presahl-deficit-10-miliard-predloni-byl-pritom-vsolidnim-prebytku>.

Sociální zabezpečeni - občan [online]. Portál veřejné správy, 2009 [cit. 2009-12-10]. Dostupný z WWW: $<$ http://portal.gov.cz/wps/portal/_s.155/716/_ps.1257/ $\mathrm{M} / \_$s. $155 / 8712$ ?s $=1086 \&$ docid $=410>$.

VEČERNÍK, J. (2005). Proměny a problémy české sociálni politiky [online]. Sociologický ústav AV ČR, [cit. 25-01-2010]. Dostupné na www: <http://sreview. soc.cas.cz/uploads/0680022d7a7151150edf6787bab27 8dd0efb5081_573_507vecernik18.pdf >.

Vláda ČR (2009). Programové prohlášeni vlády (2007) [online]. [cit. 2009-09-02]. Dostupný z WWW: $<$ http://www.vlada.cz/assets/clenove-vlady/historieminulych-vlad/prehled-vlad-cr/1993-2007-cr/mirektopolanek-2/Programove-prohlaseni-vlady_1.pdf 
Vrcholi spor o dochodky: Pre koho je druhý pilier výhodný? [online]. Investujeme.sk, 2009 [cit. 201001-10]. Dostupný z WWW: <http://www.investujeme. sk/clanky/vrcholi-spor-o-dochodky-pre-koho-jedruhy-pilier-vyhodny>.

Výnosy v penzijnich fondech - nejsou a nebudou [online]. FP finanční poradce, 2009 [cit. 2009-08-20]. Dostupný z WWW: <http://fpweb.ihned.cz/c1-36319 360-vynosy-v-penzijnich-fondech-nejsou-a-nebudou $>$.
Zákon č. 155/1995 Sb., o důchodovém pojištění, v platném znění.

Zákon č. 582/1991 Sb., o organizaci a provádění sociálního zabezpečení, v platném znění. 